\title{
EVALUATION OF ADAPTIVE MEASURES TO REDUCE CLIMATE CHANGE IMPACT ON SOIL ORGANIC CARBON STOCK IN ŽITNÝ OSTROV REGION
}

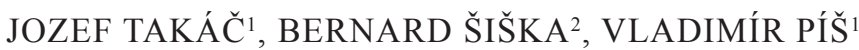 \\ ${ }^{1}$ Soil Science and Conservation Research Institute, Bratislava \\ ${ }^{2}$ Slovak University of Agriculture in Nitra
}

TAKÁC̆, J. - ŠIŠKA, B. - PÍŠ, V.: Evaluation of adaptive measures to reduce climate change impact on soil organic carbon stock in Žitný Ostrov region. Agriculture (Pol'nohospodárstvo), vol. 57, 2011, no. 3, pp. 85-95.

\begin{abstract}
Climate change impacts on soil organic carbon sequestration rate were simulated by agroecological model DAISY. Daily meteorological data for the Danubian Lowland up to 2100 were generated according to emission scenarios SRES A2 and B1 using general circulation model CGCM3.1. Effect of gradual increase of $\mathrm{CO}_{2}$ concentration in the atmosphere was taken into account. Various crop rotations as well as various management practices including irrigation and crop residuals incorporation were considered in three variants: i/ rainfed, residuals
\end{abstract}

not incorporated, ii/ irrigated, residuals not incorporated, iii/ summer crops irrigated and residuals incorporated. Modelling outputs confirm that conventional rainfed agro-technical practices without incorporation of crop residues resulted to significant loss of soil organic carbon in soil profile towards more distanced time slices. The irrigation and the incorporation of crop residuals including stems and leaves can reduce soil organic carbon losses. If it is combined with proper crop rotation the soil organic carbon stock in soil profile can even increase.

Key words: soil organic carbon, climate change, adaptive measures, crop residuals, irrigation

Technological progress, needs of growing mankind population leading to enormous consumption of fossil fuels and other natural sources resulted in the serious increase of greenhouse gas emissions and consequently in the global warming of atmosphere. It is anticipated that these processes of climate change will accelerate and become the most serious environmental problems of this century. Among economic sectors the forestry and the agriculture (both also include water management) should be the most seriously affected sectors by climate change impacts. Both positive and negative climate change impacts on agricultural production can be recognized. Fertilization effect of increased $\mathrm{CO}_{2}$ concentration in the atmosphere has positive impact on photosynthesis rate and crop yields. On the other hand the positives of elevated $\mathrm{CO}_{2}$ concentration for plant production may be suppressed if the water becomes a limiting factor and so the role of soil water regime was highlighted from the first attempt of solving this issue (Tomlain 1997; Špánik \& Šiška 2000; Šiška \& Takáč 2009; Takáč 2001 and others). Less attention has been paid to impacts of climate change on interaction among temperature regime, nutrient cycling and soil properties

Nutrient uptake in addition to physical environmental conditions may be significantly influenced by the tillage, using crops in rotation, or other agrotechnical measures. In recent years more attention was paid to the definition of soil fertility indicators in context of sustainable farming (Anderson 2003; Arshad \& Martin 2002; Shaxson 1998). They are also important in terms of emissions of greenhouse gases $\left(\mathrm{N}_{2} \mathrm{O}, \mathrm{CH}_{4}\right.$ and $\left.\mathrm{CO}_{2}\right)$ from agro-ecosystems to the atmosphere (Ball et al. 1999; Smith 2003).

RNDr. Jozef Takáč, PhD., RNDr. Vladimír Píš, PhD., Soil Science and Conservation Research Institute, 82713 Bratislava, Gagarinova 10, Slovak Republic. E-mail: j.takac@vupop.sk doc. RNDr. Bernard Šiška, CSc., Slovak University of Agriculture in Nitra, Faculty of European Studies and Regional Development, 94976 Nitra, Tr. A. Hlinku 2, Slovak Republic 
The main potential impacts on soil properties, especially on the content and quality of soil organic matter, will be indirect through increased biomass production due to the fertilization effect of elevated concentrations of $\mathrm{CO}_{2}$ in the atmosphere and increased water use efficiency (Winzeler et al. 1989). On the one hand, the quantity of crop residues supplied to the soil will increase; on the other hand, more intensive crop growth due to $\mathrm{CO}_{2}$ fertilization effect may cause a lack of nutrients in the soil. Increased temperature can lead to greater decomposition of soil organic matter but due to fertilization effect of the increased concentration of $\mathrm{CO}_{2}$ in the atmosphere more crop residues with a higher ratio of $\mathrm{C} / \mathrm{N}$ can be formed. These residues decompose slowly and can lead to negative feedback and the availability of the nutrients can be negatively affected. On knowledge of the historical development of soils and climate change scenarios Šurina and Sobocká (2005) concluded that only small changes will be recognized in soil properties and it is tended to the increase the productive potential of arable land.

There are usually four effective measures proposed to reduce negative climate change impacts in agricultural sector: change of crop, change of crop variety, shift of sowing date and irrigation use (Šiška \& Takáč 2008). Except for land use change the best adaptive measures for soil organic matter conservation are considered the agro-technological ones in sense of good agricultural practice in fertilization, cultivation, and crop residuals management (Sobocká et al. 2010).

The use of simulation models is practically the only reasonable way how to evaluate the potential of climate change impacts (including testing of adaptive measures applying to reduce its possible negative effects) in soil-plant-atmosphere system. Systems modelling that combine inputs from soil-plant-atmosphere model and various inputs from General Circulation Models (GCMs) in dependence on emission scenarios (SRES) allows us to prepare datasets describing continuously possible processes at that system in the future. Within the system modelling of those processes in agriculture there were water regime and irrigation needs (Takáč 2001 ) and potential changes in field crop yields evaluated (Šiška \& Samuhel 2007; Šiška \& Mališ 1997; Šiška \& Takáč 2008; Takáč \& Šiška 2008; Takáč \& Ššša 2009).

There were also designed several models for evaluation of carbon and nitrogen stock-movement pro- cesses in cultivated soil during the last decades of year. DNDC (Denitrification-Decomposition) model demonstrated a distinguished capacity of predicting trace gas emissions and soil organic carbon dynamics in agro-ecosystems (Li et al. 1992; Li 2000). The original purpose of developing the DNDC model was to quantify the impacts of climate change and management on greenhouse gas emissions from agricultural lands in the U.S. During the past decade, DNDC has been tested by many researchers worldwide with promising results (Brown 1995; Smith et al. 1997; Jagadeesh Babu et al. 2006; Smith et al. 2008). DNDC model is utilized first of all for evaluation of nitrous oxide in conditions of Slovakia on regional scale (Horák et al.; Šiška \& Horák 2007).

Less attention was paid to climate influences on carbon sequestration and carbon stock in soil profile. Relations between temperature and carbon stock were confirmed using RothC model in Slovak conditions (Barančíková et al. 2010). The same model was also used for evaluation of spatial distribution of carbon sequestration rate in cultivated soils of Slovakia (Tarasovičová et al. 2009).

System modelling of climate change impacts (in two variants with different SRES) on carbon sequestration rate was simulated by DAISY and CENTURY model in past. No significant trend was found in carbon sequestration rate in comparison to results found according to input data from both different SRES. Calcareous Chernozem as a very productive soil will not be affected from the point of view both of carbon loss and changes of $\mathrm{C} / \mathrm{N}$ ratio.

Model simulation of possible changes of soil organic carbon (SOC) content in climate change conditions on Žitný ostrov area is the objective of the presented paper. Proposal of adaptive measures was tested both for the use of crop rotations and application of irrigation during growing season.

\section{MATERIAL AND METHODS}

Climate change scenarios used for impacts evaluation are based on emission scenarios (SRES). SRES are constructed according to supposed population rate as well as economical and technological progress. The highest rate of emissions is supposed for SRES A2 on the other side of scale is SRES B1 (IPCC 2007). 
Emission scenarios are basis both for atmospheric $\mathrm{CO}_{2}$ concentrations (Fig. 1) and for preparing of consistent meteorological data respecting general circulation models (GCMs).

Meteorological data for climate change conditions were outputs from global circulation model CGCM3.1 (Lapin et al. 2006) in variants of IPCC SRES A2 and SRES B1 (IPCC 2007). Datasets for both SRES A2 and SRES B1 consist of daily global radiation, air mean temperature and precipitation for period of years 2001-2100 for reference climatic station Hurbanovo. This dataset is supposed to represent the Danubian lowland region. Basic statistics of air mean temperatures and precipitation are given in Table 1.

Evaluation of the climate change impacts on carbon sequestration rate in different soil water regime under field crops was based on simulations by agro-ecological model DAISY (Hansen et al. 1990). DAISY is a

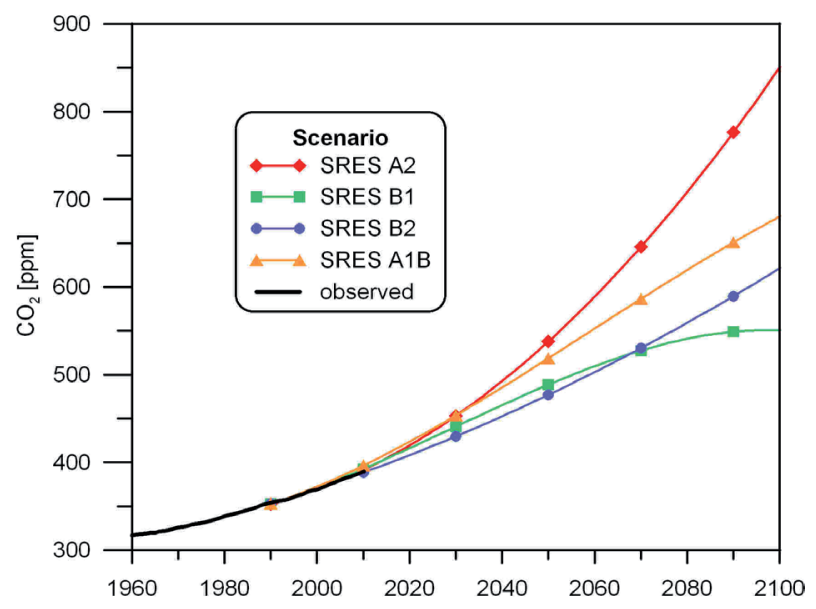

Fig. 1. $\mathrm{CO}_{2}$ concentration in atmosphere [ppm] for different SRES one-dimensional model simulating water, energy, nitrogen and soil organic matter balance. Crop development and yield is possible to simulate in dependence on crop rotation and various management strategy. DAISY simulates plant growth and development, including the accumulation of dry matter and nitrogen content in different plant parts. The main plant-growth processes considered in DAISY are photosynthesis, respiration, partitioning of assimilates, stress factors and leaf and root development.

The model recognizes three types of organic mass in soil: added organic matter (AOM), soil organic matter (SOM) and soil microbial biomass (SMB), each of them can be classified according to decomposition rate into two pools: the first pool with a slow turnover and the second one with a faster turnover rate. The model allows constructing complex management strategies (Hansen et al. 1990; Abrahamsen \& Hansen 2000). Model DAISY was tested in several inter-model comparison studies (Diekkrüger et al. 1995; Smith et al. 1997). The model was parameterized and validated according to results on biomass accumulations, yields and soil nitrogen and carbon dynamics from field trials in Slovakia (Šiška \& Takáč 2008).

DAISY model calculates photosynthesis rate using a light saturation response curve. The effect of $\mathrm{CO}_{2}$ concentration was included to the DAISY parameterization according to light saturated photosynthesis rate and initial light use efficiency. Efficiency of photo synthetically active radiation for crops included into rotations was recalculated in dependence upon $\mathrm{CO}_{2}$ concentration in the atmosphere (Cure \& Acock 1986) for emission scenarios SRES A2 and SRES B1 (IPCC 2007). Gradual increase of $\mathrm{CO}_{2}$ concentration was taken into account (Table 2).

$\mathrm{T}$ a b 1 e 1

Long-term mean air temperatures $\mathrm{T}\left[{ }^{\circ} \mathrm{C}\right]$ and precipitation totals $\mathrm{R}[\mathrm{mm}]$ in Hurbanovo according to SRES A2 and B1

\begin{tabular}{|c|c|c|c|c|c|c|c|}
\hline \multirow{2}{*}{ SRES } & \multirow{2}{*}{ Season } & \multicolumn{2}{|c|}{$2011-2040$} & \multicolumn{2}{|c|}{$2041-2070$} & \multicolumn{2}{c|}{$2071-2100$} \\
\cline { 3 - 8 } & & $\mathrm{T}\left[{ }^{\circ} \mathrm{C}\right]$ & $\mathrm{R}[\mathrm{mm}]$ & $\mathrm{T}\left[{ }^{\circ} \mathrm{C}\right]$ & $\mathrm{R}[\mathrm{mm}]$ & $\mathrm{T}\left[{ }^{\circ} \mathrm{C}\right]$ & $\mathrm{R}[\mathrm{mm}]$ \\
\hline \multirow{2}{*}{$\mathrm{A} 2$} & Year & 11.6 & 563 & 12.6 & 607 & 14.2 & 641 \\
& Warm halfyear & 18.2 & 289 & 19.1 & 321 & 20.7 & 327 \\
\hline \multirow{2}{*}{$\mathrm{B} 1$} & Year & 11.6 & 573 & 12.2 & 612 & 12.4 & 605 \\
& Warm halfyear & 18.0 & 324 & 18.5 & 322 & 18.9 & 322 \\
\hline
\end{tabular}


As resulted from Table 2 the corn maize values are specific comparing to other crops. This fact is caused by the type of photosynthesis: corn maize belongs to the group of $\mathrm{C} 4$ plants while the other crops to the group of $\mathrm{C} 3$ plants. $\mathrm{CO}_{2}$ biomass response curve of $\mathrm{C} 3$ plants is more sensitive as compared to $\mathrm{C} 4$ plants.

The representative soil profile was designed on the base of statistical analyses of hydro physical and chemical properties of soils in the Žitný ostrov region (Takáč \& Košč 1995). Deep loamy Chernozems with high humus content in ploughing layer were found as dominant soils in the Žitný ostrov region (Table 3). The essential part of organic matter content is concentrated in upper $80 \mathrm{~cm}$ layer of soil profile. Each soil horizon was defined by sand, silt and clay contents, parameters of retention curve, saturated hydraulic conductivity, humus content and $\mathrm{C} / \mathrm{N}$ ratio.

Alternatives of simulations and model parameterization were designed for the purpose of the interrelation evaluations among atmospheric $\mathrm{CO}_{2}$, climatic conditions, irrigation regime, nitrogen nutrition, manure and yield potential of field crops involved in cropping rotations. Daily data on soil organic carbon stocks according to different fractions in different soil layers were evaluated in upper $100 \mathrm{~cm}$ of soil profile in monthly step.

Crops (corn maize, spring barley, alfalfa, winter wheat, oil seed rape, sugar beet, potato and pea) in crop rotations were arranged in 10-years cycles (Table 4) with different fertilization dozens, irrigation sched-

$\mathrm{T}$ a b 1 e 2

$\mathrm{CO}_{2}$ concentration in atmosphere and radiation efficiency (coefficients) for different crops in time slices according to SRES A2 and SRES B2

\begin{tabular}{|c|c|c|c|c|c|c|c|c|c|c|}
\hline \multirow[t]{2}{*}{ Year } & \multicolumn{2}{|c|}{$\begin{array}{c}\text { Concentration } \mathrm{CO}_{2} \\
{[\mathrm{ppm}]}\end{array}$} & \multicolumn{2}{|c|}{ Potato } & \multicolumn{2}{|c|}{ Winter wheat } & \multicolumn{2}{|c|}{ Spring barley } & \multicolumn{2}{|c|}{ Corn maize } \\
\hline & $\mathrm{A} 2$ & B1 & $\mathrm{A} 2$ & B1 & A2 & B1 & A2 & B1 & $\mathrm{A} 2$ & B1 \\
\hline 2000 & 369 & 369 & 1.01 & 1.01 & 1.03 & 1.03 & 1.02 & 1.02 & 1.00 & 1.00 \\
\hline 2010 & 391 & 393 & 1.02 & 1.02 & 1.05 & 1.05 & 1.03 & 1.03 & 1.01 & 1.01 \\
\hline 2020 & 419 & 416 & 1.03 & 1.03 & 1.07 & 1.07 & 1.04 & 1.04 & 1.01 & 1.01 \\
\hline 2030 & 451 & 441 & 1.04 & 1.03 & 1.10 & 1.09 & 1.05 & 1.05 & 1.01 & 1.01 \\
\hline 2040 & 493 & 465 & 1.05 & 1.04 & 1.13 & 1.11 & 1.07 & 1.06 & 1.02 & 1.02 \\
\hline 2050 & 538 & 489 & 1.06 & 1.05 & 1.17 & 1.13 & 1.09 & 1.07 & 1.03 & 1.02 \\
\hline 2060 & 589 & 510 & 1.08 & 1.05 & 1.21 & 1.15 & 1.11 & 1.08 & 1.03 & 1.02 \\
\hline 2070 & 646 & 527 & 1.10 & 1.06 & 1.26 & 1.16 & 1.13 & 1.08 & 1.04 & 1.02 \\
\hline 2080 & 708 & 541 & 1.11 & 1.06 & 1.31 & 1.17 & 1.16 & 1.09 & 1.05 & 1.03 \\
\hline 2090 & 776 & 549 & 1.14 & 1.07 & 1.37 & 1.18 & 1.19 & 1.09 & 1.05 & 1.03 \\
\hline 2100 & 850 & 551 & 1.16 & 1.07 & 1.43 & 1.18 & 1.22 & 1.09 & 1.06 & 1.03 \\
\hline
\end{tabular}

T a b 1 e 3

Simulated soil profile characteristics

\begin{tabular}{|c|c|c|c|c|c|c|}
\hline $\begin{array}{c}\text { Horizon } \\
{[\mathrm{m}]}\end{array}$ & $\begin{array}{c}\text { Bulk density } \\
{\left[\mathrm{g} \mathrm{cm}^{3}\right]}\end{array}$ & $\begin{array}{c}\text { Porosity } \\
{[-]}\end{array}$ & $\begin{array}{c}\text { Field capacity } \\
{[-]}\end{array}$ & $\begin{array}{c}\text { Wilting } \\
\text { point } \\
{[-]}\end{array}$ & $\begin{array}{c}\text { Saturated } \\
\text { hydraulic } \\
\text { conductivity } \\
{\left[\mathrm{m} \mathrm{d}^{-1}\right]}\end{array}$ \\
\hline $0-0.45$ & 1.33 & 0.499 & 0.327 & 0.187 & 0.31 & $\begin{array}{c}\text { Humus } \\
{[\%]}\end{array}$ \\
$0.45-0.80$ & 1.46 & 0.448 & 0.316 & 0.133 & 0.38 & 0.35 \\
$>0.80$ & 1.43 & 0.463 & 0.347 & 0.198 & 0.4 \\
\hline
\end{tabular}


ules and crop residuals management. Three levels of irrigation were simulated for each crop rotation: M0 - without irrigation, M1 - each crop irrigated a M2 - irrigated only crops grown during summer season, crops grown during spring were rainfed (spring barley, winter wheat and oil seed rape). Except for stubble crop residuals were removed in M0 and M1. Crop residuals including stems and leaves were incorporated in $\mathrm{M} 2$ variant.

Irrigation was applied automatically after decreasing of soil water content below $50 \%$ of available water capacity for each of evaluated crop. 10 days irrigation frequency (interval between 2 applications) was set up as lower limit for crops except for potato and pea where the limit was set up to 7 days. This restriction assumption was chosen because limited irrigation water supply is expected in future climatic conditions.

Irrigation season depends on crop development stage. The goal was to cover water demand of crops in important development stages, especially when insufficient water supply in soil profile can reduce yield significantly.

Simulation schedules of fertilization strategy respected good practice in agriculture as well as expert recommendations. Dozens of nitrogen in mineral form for different crops are given in the Table 5. Except for mineral nitrogen there were applied $40 \mathrm{tha}^{-1}$ of manure for sugar beet and maize crops in autumn of previous

$\mathrm{T}$ a b 1 e 4

Crop rotation schedule for DAISY model simulation

\begin{tabular}{|c|c|c|c|c|}
\hline Year & CR1 & CR2 & CR3 & CR4 \\
\hline 1 & alfalfa & winter wheat & sugar beet & corn maize \\
2 & alfalfa & oil seed rape & winter wheat & corn maize \\
3 & alfalfa & winter wheat & oil seed rape & spring barley \\
4 & winter wheat & corn maize & spring barley & oil seed rape \\
5 & oil seed rape & winter wheat & corn maize & spring barley \\
6 & winter wheat & sugar beet & spring barley & pea \\
7 & oil seed rape & spring barley & pea & winter wheat \\
8 & corn maize & potato & winter wheat & oil seed rape \\
9 & potato & spring barley & oil seed rape & winter wheat \\
10 & spring barley & pea & winter wheat & potato \\
\hline
\end{tabular}

$\mathrm{T}$ a b 1 e 5

Dozens of mineral nitrogen for DAISY model simulation

\begin{tabular}{|c|c|c|c|}
\hline Crop & $\begin{array}{c}\text { Before sowing } \\
{\left[\mathrm{kg} \mathrm{N} \mathrm{ha}^{-1}\right]}\end{array}$ & $\begin{array}{c}\text { After sowing } \\
{\left[\mathrm{kg} \mathrm{N} \mathrm{ha}^{-1}\right]}\end{array}$ \\
\hline Winter wheat & 40 & 80 & 120 \\
Spring barley & 40 & 20 & 60 \\
Oil seed rape & 50 & 70 & 120 \\
Corn maize & 120 & 0 & 120 \\
Sugar beet & 40 & 60 & 100 \\
Alfalfa & 30 & 0 & 30 \\
Potato & 80 & 20 & 100 \\
Pea & 30 & 0 & 30 \\
\hline
\end{tabular}


year (1st year) and $20 \mathrm{t} \mathrm{ha}^{-1}$ of manure before sowing of oil seed rape. During 10 years there was applied $80 \mathrm{tha}^{-1}$ of manure in rotations CR1, CR2 and CR4 and $120 \mathrm{t} \mathrm{ha}^{-1}$ in CR3 rotation.

\section{RESULTS AND DISCUSSION}

Conventional agro-technical practices without input of crop residuals (M0, M1) can lead to significant SOC loss in soil profile towards more distanced time slices applying both SRES A2 and SRES B1 (Table 6).

$\mathrm{T}$ a b 1 e 6

Changes of soil organic carbon (in per cents) in soil profile for time slices 2040, 2070, 2100 aggregated by management practices and rotations

\begin{tabular}{|c|c|c|c|c|c|}
\hline \multirow{2}{*}{ SRES } & \multirow{2}{*}{ Variant } & \multirow{2}{*}{ Crop rotation } & \multicolumn{3}{|c|}{ Time slice } \\
\hline & & & 2040 & 2070 & 2100 \\
\hline \multirow{15}{*}{$\mathrm{A} 2$} & \multirow{5}{*}{ M0 } & CR1 & -10 & -20 & -32 \\
\hline & & CR2 & -9 & -19 & -31 \\
\hline & & CR3 & -7 & -14 & -24 \\
\hline & & CR4 & -9 & -19 & -30 \\
\hline & & Mean & -9 & -18 & -29 \\
\hline & \multirow{5}{*}{ M1 } & CR1 & -9 & -19 & -30 \\
\hline & & CR2 & -9 & -18 & -29 \\
\hline & & CR3 & -6 & -13 & -23 \\
\hline & & CR4 & -9 & -19 & -29 \\
\hline & & Mean & -8 & -17 & -28 \\
\hline & \multirow{5}{*}{ M2 } & CR1 & -4 & -7 & -13 \\
\hline & & CR2 & -3 & -5 & -10 \\
\hline & & CR3 & +2 & +4 & +4 \\
\hline & & CR4 & -2 & -5 & -8 \\
\hline & & Mean & -2 & -3 & -7 \\
\hline \multirow{15}{*}{ B1 } & \multirow{5}{*}{ M0 } & CR1 & -10 & -20 & -30 \\
\hline & & CR2 & -10 & -20 & -29 \\
\hline & & CR3 & -7 & -14 & -21 \\
\hline & & CR4 & -9 & -18 & -28 \\
\hline & & Mean & -9 & -18 & -27 \\
\hline & \multirow{5}{*}{ M1 } & CR1 & -9 & -18 & -28 \\
\hline & & CR2 & -9 & -18 & -27 \\
\hline & & CR3 & -6 & -13 & -19 \\
\hline & & CR4 & -9 & -18 & -29 \\
\hline & & Mean & -8 & -17 & -26 \\
\hline & \multirow{5}{*}{ M2 } & CR1 & -4 & -8 & -13 \\
\hline & & CR2 & -3 & -6 & -7 \\
\hline & & CR3 & +1 & +4 & +5 \\
\hline & & CR4 & -2 & -3 & -5 \\
\hline & & Mean & -2 & -3 & -5 \\
\hline
\end{tabular}


The highest SOC loss was found in variants without irrigation (M0) and input of crop residuals (in range from -24 to $-32 \%$ applying SRES A2 or from -21 to $-30 \%$ applying SRES B1). A little more promising results were found in variants with irrigation in summer season (M1). If compared M0 and M1 variants the irrigation reduced losses in SOC stock by about $2-11 \%$. Rotations and agro-technical practices play also important role in carbon sequestration rate. The smallest SOC losses were simulated for CR3 rotation, where $40 \mathrm{tha}^{-1}$ more manures were applied as compared with other rotations.

Simulation confirmed that the irrigation and the incorporation of crop residuals can reduce losses in soil organic carbon stock (M2 variant). If combined with proper crop rotation (CR3 rotation) the carbon stock in soil profile can even increase by about $2 \%$ when comparing stock at the beginning and end of the century. Comparing SRES A2 and SRES B1 we can conclude that the former scenario is more favourable from the point of view of carbon stock formation.

Besides corn maize (C4 plant) simulated yields of field crops were positively influenced by increasing concentrations of the atmospheric $\mathrm{CO}_{2}$. Trend of increasing biomass yields has slowed after reaching the level of a double concentration of $\mathrm{CO}_{2}$ in the atmosphere compared to the current situation.

Drought conditions can reduce transfer of assimi- lates to the grain. On rainfed soils the dominant part of biomass yields consists of straw and leaves. Proportion of grain is higher in irrigated variants than in the rainfed ones. Except for heat stress the grain yields were also influenced by available water during growing season (Table 7). Irrigation efficiency towards more distanced time slices gradually decreased. On the other hand the irrigation was found as an effective measure that can stabilize yields of summer season crops. Comparing simulated corn maize yields in rainfed and irrigated variants the increase in range from 71 to 84 per cents was found.

The higher are phytomass yields the higher are root residuals. Irrigation can support favourable soil water regimes leading to high root biomass production but evoke also processes of mineralization and so net production does not increase in each year. Gradual increase of carbon content in crop root residuals was simulated for all variants over the simulated period. This tendency slows down at the end of the evaluated period. Root residuals were higher by about 25 to $35 \%$ (irrigation during growing season of crops) and 18 to $24 \%$ (irrigation during summer season only) respectively in irrigated variants comparing to rainfed ones. The highest irrigation efficiency was found in time slice 2011-2040. High biomass yield and corresponding high soil organic carbon was found only if crop residuals were incorporated into soil (variant M2)

$\mathrm{T}$ a

Climate change impact (SRES A2 and B1) on mean phytomass yields [t DM ha ${ }^{-1}$ for rainfed and irrigated variants

\begin{tabular}{|c|c|c|c|c|c|c|c|}
\hline \multirow{2}{*}{ Crop } & \multirow{2}{*}{ SRES } & \multicolumn{2}{|c|}{$2011-2040$} & \multicolumn{2}{|c|}{$2041-2070$} & \multicolumn{2}{|c|}{$2071-2100$} \\
\hline & & rainfed & irrigated & rainfed & irrigated & rainfed & irrigated \\
\hline \multirow{2}{*}{ Winter wheat } & A2 & 12.85 & 16.73 & 15.73 & 18.05 & 17.85 & 18.66 \\
\hline & B1 & 13.26 & 17.20 & 14.66 & 17.42 & 14.76 & 17.72 \\
\hline \multirow{2}{*}{ Spring barley } & A2 & 9.50 & 10.80 & 10.98 & 11.40 & 11.99 & 12.16 \\
\hline & B1 & 9.71 & 10.71 & 10.47 & 11.11 & 10.60 & 11.31 \\
\hline \multirow{2}{*}{ Corn maize } & $\mathrm{A} 2$ & 9.67 & 17.05 & 9.62 & 16.22 & 9.45 & 15.40 \\
\hline & B1 & 10.70 & 17.37 & 10.18 & 17.21 & 10.18 & 16.89 \\
\hline \multirow{2}{*}{ Sugar beet } & A2 & 7.86 & 17.77 & 8.54 & 19.12 & 8.38 & 19.72 \\
\hline & B1 & 8.79 & 18.21 & 8.79 & 18.50 & 9.09 & 18.99 \\
\hline \multirow{2}{*}{ Potato } & $\mathrm{A} 2$ & 6.25 & 16.79 & 7.28 & 19.20 & 7.89 & 20.06 \\
\hline & B1 & 6.83 & 17.22 & 7.35 & 17.91 & 7.48 & 19.44 \\
\hline
\end{tabular}



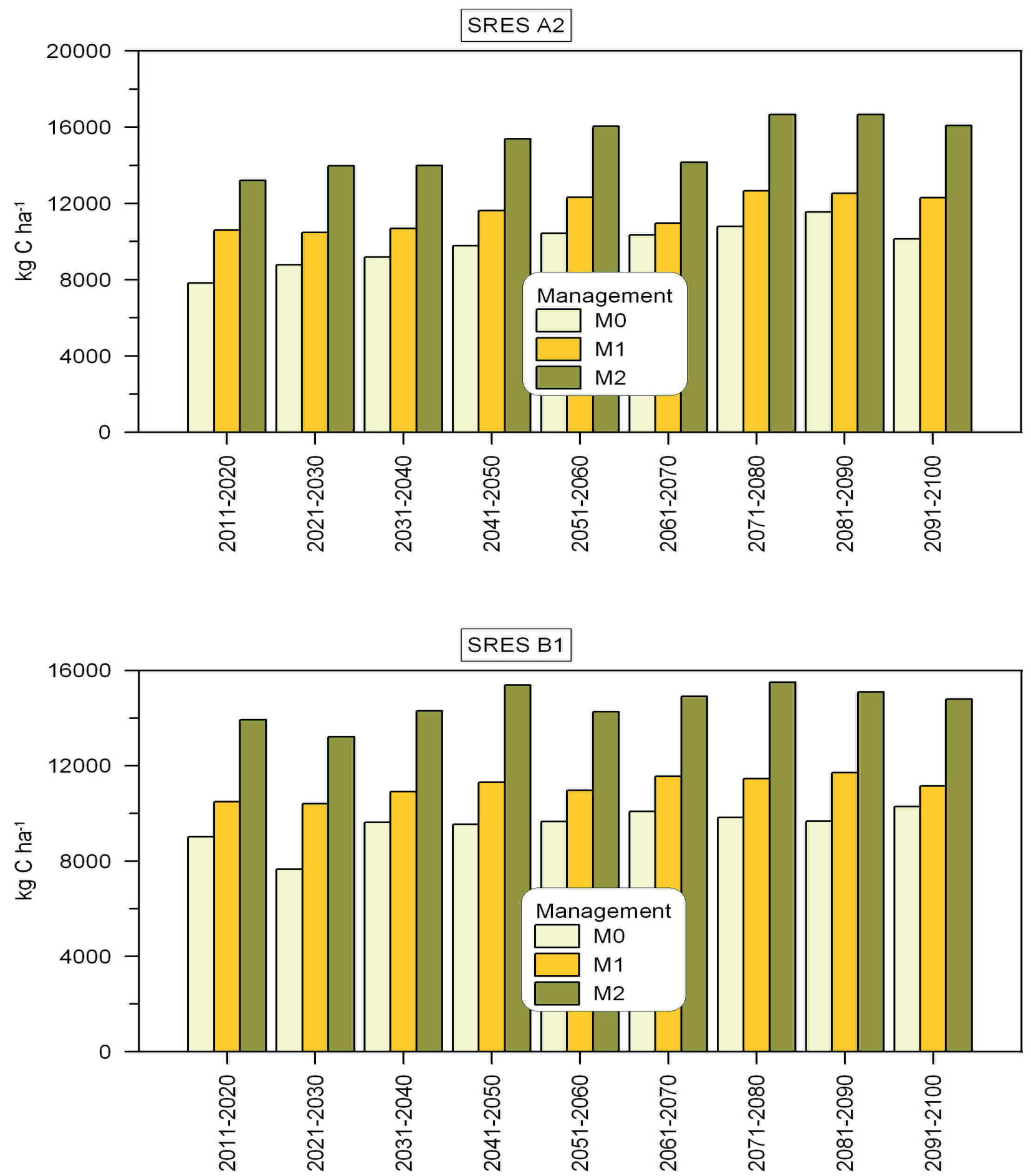

Fig. 2. Carbon content in incorporated crop residuals $\left[\mathrm{kg} \mathrm{C} \mathrm{ha}^{-1}\right]$ aggregated by management practices and emission scenarios (A2 - up and B1 - down) in time slices 2011-2100

(Fig. 2). The SOC stock in irrigated variants without incorporated crop residuals was low but higher than one in rainfed variant (M0). Despite the removal of crop residual in irrigated variants the biomass was still high enough to enrich soil profile by carbon. This fact is probably influenced by character of climate change scenarios and consequently the biomass rate dynamics. Positive $\mathrm{CO}_{2}$ effect on photosynthesis rate can take 
place only until the soil-atmospheric properties do not discontinue or limit the physiological processes. Negative effects of high temperatures combined with insufficient supply of water in soil profile can reverse the course of events especially in generative phases of growing season although the $\mathrm{CO}_{2}$ will still affect biomass yield significantly.

CENTURY model offered similar results in conditions of Slovak Republic (Sobocká et al. 2007). Crop rotations and conventional management with irrigation lead to very slightly decreasing in organic carbon supplies up to 2090. Very moderately decreasing trend in carbon stock was accompanied with retardation of mineralization rate in rainfed variants. Excluding fertilization and irrigation in agricultural practice can result in drastic decrease of the soil organic carbon in the future climate change.

SOC losses were simulated also with EPIC model (Balkovič et al. 2011) for to emission scenarios SRES A2 and SRES B2 up to time slice 2050. We could expect that the increasing temperatures in future climate accelerate the decomposition of the soil organic carbon as expected by Smith et al. (2008).

\section{CONCLUSIONS}

In contrast with other studies the model application allows take into account also effects of atmospheric $\mathrm{CO}_{2}$ on field crop yields and consequent stock rate in soils of Slovak Republic.

According to DAISY simulation the significant carbon stock decreases can be expected as a result of climate change scenarios (SRES A2, SRES B1) impacts in variant of conventional rainfed management without input of crop residuals into the soil. Better results but still decrease of carbon stock was found if irrigation is applied. Only the combination of the crop residuals inputs into the soil with adequate irrigation can store organic carbon in soil or the carbon lost is to be predicted as very small.

Global warming without a proposal and the consequent application of the effective adaptive measures (especially irrigation) can lead to significant SOC stock losses in conditions of Slovak Republic from -14 to $-20 \%$ in time slice 2070 and from -19 to $-32 \%$ in time slice 2100.

We can conclude on the base of DAISY as well as
DNDC modelling (Horák \& Šiška 2010) that soil fertility (including steady level of carbon stock) in climate change conditions requires to adopt complex of agro-technical measures. Except for use of the „more carbonized" plants in crop rotations the irrigation will play important role. Combination of both measures can accelerate carbon stock by 4 or $5 \%$ in climatic conditions of time slice 2070 or 2100 respectively.

Acknowledgements: We gratefully acknowledge the support of the Grant Agency of the Slovak Republic: VEGA 1/0866/10: Proposal of adaptive measures to reduce negative climate change impacts on agricultural landscape of Danubian Lowland.

\section{REFERENCES}

ABRAHAMSEN, P. - HANSEN, S. 2000. Daisy: an open soil - plant - atmosphere system model. In Environmental Modelling \& Software, vol. 15, 2000, pp. 313-330. DOI: 10.1016/S1364-8152(00)00003-7.

ANDERSON, T.H. 2003. Microbial eco-physiological indicators to access soil quality. In Agriculture, Ecosystems \& Environment, vol. 98, 2003, pp. 285-293. DOI:10.1016/ S0167-8809(03)00088-4.

ARSHAD, M.A. - MARTIN, S. 2002. Identifying critical limits for soil quality indicators in agro-ecosystems. In $\mathrm{Ag}$ riculture, Ecosystems \& Environment, vol. 88, 2002, pp. 153-160. DOI: 10.1016/S0167-8809(01)00252-3.

BALL, B.C. - SCOTT, A. - PARKER, J.P. 1999. Field $\mathrm{N}_{2} \mathrm{O}$, $\mathrm{CO}_{2}$ and $\mathrm{CH}_{4}$ fluxes in relation to tillage, compaction and soil quality in Scotland. In Soil \& Tillage Research, vol. 53, 1999, pp. 29-39. DOI:10.1016/S0167-1987(99)000744 .

BALKOVIČ, J. - SCHMID, E. - SKALSKÝ, R. - NOVÁKOVÁ, M. 2011. Modelling soil organic carbon changes on arable land under climate change - A case study analysis of the Kočín farm in Slovakia. In Soil \& Water Research, vol. 6, 2011, no. 1, pp. 30-42.

BARANČÍKOVÁ, G. - HALÁS, J. - GUTTEKOVÁ, M. - MAKOVNÍKOVÁ, J. - NOVÁKOVÁ, M. - SKALSKÝ, R. - TARASOVIČOVÁ, Z. 2010. Application of RothC model to predict soil organic carbon stock on agricultural soils of Slovakia. In Soil \& Water Research, vol. 5, 2010, no. 1, pp. 1-9.

BROWN, L. 1995. Who will feed China? Wake up call for a small Planet. Washington, USA : Norton \& Company. 1995. 163 pp. ISBN 0-393-31049-X.

CURE, J.D. - ACOCK, B. 1986. Crop responses to carbon dioxide doubling: a literature survey. In Agricultural and Forest Meteorology, vol. 38, 1986, pp. 127-145. DOI: 10.1016/0168-1923(86)90054-7.

DIEKKRÜGER, B. - SÖNDGERATH, D. - KERSEBAUM, K.C. - McVOY, C.W. 1995. Validity of agroecosystem models: a comparison of results of different models applied to the 
same data set. In Ecological Modelling, vol. 81, 1995, no. 1-3, pp. 3-29. DOI:10.1016/0304-3800(94)00157-D.

HANSEN, S. - JENSEN, H.E. - NIELSEN, N.E. - SVENDSEN, H. 1990. DAISY - a soil plant system model. Danish simulation model for transformation and transport of energy and matter in the soil-plant-atmosphere system. Copenhagen : National Agency for Environmental Protection, 1990. 272 p. ISBN 87-503-8790-1.

HORÁK, J. - ŠIŠKA, B. - SUCHOMEL, J. 2011. Using two different approaches to evaluate nitrous oxide $\left(\mathrm{N}_{2} \mathrm{O}\right)$ emissions from agricultural soils in the Slovak Republic. In Meteorologický časopis (Meteorological Journal), vol. 13, 2011, (in press).

IPCC, 2007. Climate Change 2007. The physical science basis. Contribution of working group I to the fourth assessment report of the Intergovernmental Panel on Climate Change. In SOLOMON, S. - QIN, D. - MANNING, M. - CHEN, Z. - MARQUIS, M. - AVERYT, K.B. - TIGNOR, M. MILLER, H.L. (eds.). Cambridge, UK and New York, USA : Cambridge University Press, 2007. 996 pp. ISBN 978-0521-70596-7.

JAGADEESH BABU, Y. - LI, C. - FROLKING, S. - NAYAK, D.R. - ADHYA, T.K. 2006. Field validation of DNDC model for methane and nitrous oxide emissions from ricebased production system of India. In Nutrient Cycling in Agroecosystem, vol. 74, 2006, no. 2, pp. 157-174. DOI: 10.1007/s 10705-005-6111-5.

LAPIN, M. - MELO, M. - DAMBORSKÁ, I. - VOJTEK, M. - MARTINI, M. 2006. Physically and statistically plausible downscaling of daily GCMs outputs and selected results. In Acta Meteorologica Universitatis Comenianae, vol. $X X X I V, 2006$, pp. 35-57.

LI, C. - FROLKING, S. - FROLKING, T.A. 1992. A model of nitrous oxide evolution from soil driven by rainfall events: Model structure and sensitivity. In Journal of Geophysical Research, vol. 97, 1992, no. D9, pp. 9759-9776.

LI, C. 2000. Modeling trace gas emissions from agricultural ecosystems. In Nutrient Cycle Agroecosystem, vol. 58, 2000, no. 1-3, pp. 259-276. DOI: 10.1023/A:1009859006242.

SHAXSON, T.F. 1998. Concepts and indicators for assessment of sustainable land use. In BLUME, H.P. - EGER, H. FLEISCHHAUER, E. -HEBEL, A. - REIJ, C. - STEINER, K.G. (Eds.): Advances in Geoecology 31: Towards sustainable land use. Reiskirchen, Germany : Catena Verlag, 1998. ISBN 3-923381-42-5. pp. 11-19.

SMITH, K.A. 2003. Soil-atmosphere interaction. In BENBI, D.K. -NIEDER, R. (Eds.). Handbook of processes and modeling in the soil-plant system. New York: The Haworth Press Inc., 2003. ISBN 978-1560229155. pp. 313-343.

SMITH, P. - SMITH, J.U. - POWLSON, D.S. - McGILL, W.B. - ARAH, J.R.M. - CHERTOV, O.G. - COLEMAN, K. - FRANKO, U. - FROLKING, S. - JENKINSON, D. S. - JENSEN, L.S. - KELLY, R.H. - KLEIN-GUNNEWIEK, H. - KOMAROV, A.S. - LI, C. -MOLINA, J.A.E. - MUEller, T. - PARTON, W.J. - THORNLEY, J.H.M. - WHITMORE, A.P. 1997. A comparison of the performance of nine soil organic matter models using datasets from seven long-term experiments. In Geoderma, vol. 81, 1997, no. 1-2, 1997, pp. 153-225.

SMITH, W.N. - GRANT, B.B. - DESJARDING, R.L. - ROCHETTE, P. - DRURY, C.F. - LI, C. 2008. Evaluation of two process-based models to estimate $\mathrm{N}_{2} \mathrm{O}$ emissions in eastern Canada. In Canadian Journal of Soil Science, vol. 88, 2008, no. 2, pp. 251-260.

SOBOCKÁ, J. - BALKOVIČ, J. - LAPIN, M. 2007. A CENTURY 5 model using for estimation of soil organic matter behaviour at predicted climate change. In Soil \& Water Research, vol. 2, 2007, no. 1, pp. 25-34.

SOBOCKÁ, J. - DODOK, R. - HRÍBIK, J. - FULAJTÁR, E. - TAKÁČ, J. - TARASOVIČOVÁ, Z. 2010. Proposal of adaptive measures on soil for mitigation of climate change impacts. Bratislava : VÚPOP, 2010. 64 pp. ISBN-978-8089128-64-8. (in Slovak)

ŠIŠKA, B. - HORÁK, J. 2007. N 2 O Emissions from sandy loam soils of the Danubian Lowland in conditions of climate change. In Meteorologický časopis (Meteorological Journal), vol. 10, 2007, no. 1, pp. 21-26.

ŠIŠKA, B. - MALIŠ, J. 1997. Supposed changes in production of winter wheat in consequence of climate change in Danubian Lowland up to Year 2075. In National Climate Programme of the Slovak Republic. NKP 7/97 - Contribution to the climate change scenarios for Slovakia. Bratislava : MŽP SR, SHMÚ, 1997. ISBN 80-88907-02-0, pp. 84-92. (in Slovak)

ŠIŠKA, B. - SAMUHEL, P. 2007. Modeling climate change impact on maize (Zea mays L.) yields in conditions of the Danubian lowland. In Meteorologický časopis (Meteorological Journal), 2007, 2, pp. 81-84.

ŠIŠKA, B. - TAKÁC̆, J. 2008. Climate change and agriculture of the Slovak Republic. Impacts, adaptive measures and possible solutions. Study of the Slovak Bioclimatological Society of SAS XXIV., vol. XXI, Zvolen : SBkS, 2008. 69 pp. ISBN-978-80-228-2009-7. (in Slovak)

ŠIŠKA, B. - TAKÁČ, J. 2009. Drought analyses of agricultural regions as influenced by climatic conditions in the Slovak Republic. In Idöjárás : Quarterly Journal of the Hungarian Meteorological Service, vol. 113, 2009, no. 1-2, pp. $135-143$.

ŠPÁNIK, F. - ŠIŠKA, B. 2000. Energetic and water securing of vegetative summer in the climate change conditions. In National Climate Programme of the Slovak Republic. NKP 9/00. Bratislava : MŽP SR, SHMÚ, 2000. ISBN 80-8890708-X, pp. 98-106. (in Slovak)

ŠURINA, B. - SOBOCKÁ, J. 2005. Current climatic change and soils of Slovakia. In Proceedings of Soil Science and Conservation Research Institute 27, Bratislava : VÚPOP, 2005. ISBN 80-89128-17-3. pp. 147-154.

TAKÁC̆, J. 2001. Climate change impacts on water balance in agricultural landscape. In National Climate Programme of the Slovak Republic. NKP 10/01 - Climate change monitoring in Slovakia and possible consequences. Bratislava : MŽP SR, SHMÚ, 2001. ISBN 80-88907-24-1.pp. 16-26. (in Slovak)

TAKÁC̆, J. - ŠIŠKA, B. 2008. Climate change impacts on crop yields on Danubian Lowland. In LAPIN, M. - NEJEDLÍK, P. (eds). In National climate programme of the Slovak Republic. NKP 12/08 - Climate change impacts and adaptation measures. Bratislava : MŽP SR, SHMÚ, 2008. ISBN 978-80-88907-63-3.pp. 113-122. (in Slovak)

TAKÁČ, J. - ŠIŠKA, B. 2009. Climate change impact on spring barley and winter wheat yields on Danubian Lowland. In STřELCOVÁ, K. - MATYAS, C. - KLEIDON, A. - LAPIN, 
M. - MATEJKA, F. - BLAŽENEC, M. - ŠKVARENINA, J.
- HOLECY, J. (eds): Bioclimatology and Natural Hazards. 2009, XVI., Springer Science+Business Media B.V., 2009. ISBN 978-1-4020-8875-9, pp. 283-288.

TARASOVIČOVÁ, Z. - NOVÁKOVÁ, M. - SKALSKÝ, R. - BALKOVIČ, J. 2009. Geografical database of RothC model inputs on weather, soil and land use. In Proceedings of Soil Science and Conservation Research Institute 31, Bratislava : VÚPOP, 2009. ISBN 978-80-89128-59-4, pp. 201-210. (in Slovak)
TOMLAIN, J. 1997. Model computation of the climate change impacts upon soil moisture. In National Climate Programme of the Slovak Republic. NKP 7/97 - Contribution to the climate change scenarios for Slovakia. Bratislava : MŽP SR, SHMÚ, 1997. ISBN 80-88907-02-0, pp. 68-83. WINZELER, M. - MSCULLOUGH, D.E. - HUNT, L.A. 1989 Leaf gas exchange and plant growth of winter rye, triticale, and wheat under contrasting temperature regimes. In Crop Science, vol. 29, 1989, no. 5. pp. 1256-1260.

Received: June, $14^{\text {th }}, 2011$ 